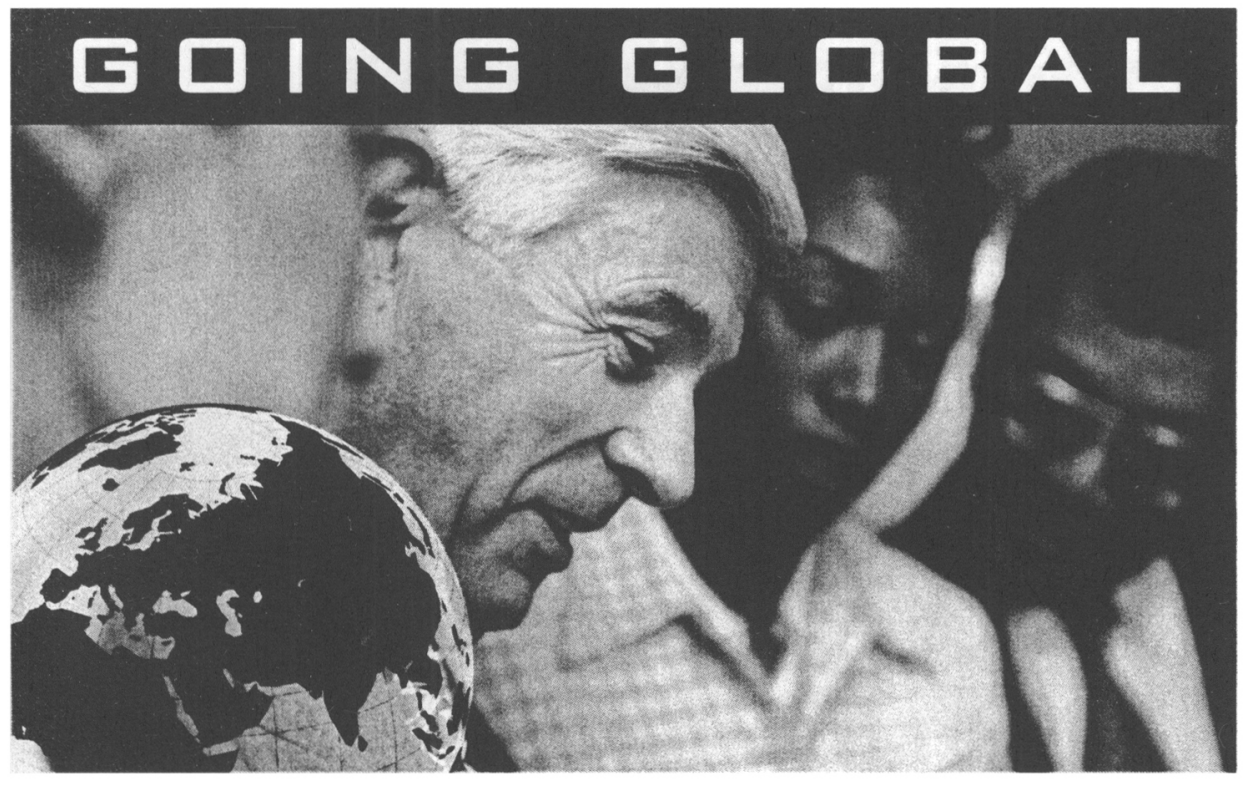

\section{Taiwan in The} Global Economy

From an Agrarian Economy to an Exporter of High-Tech Products Edited by Peter C.Y. Chow Foreword by Robert E. Lipsey

Taiwan's postwar economic development path is analyzed with a case study of its structural transformation.

$2002 \cdot 328$ pages $\cdot 0-275-97079-5 \cdot \$ 67.95$

\section{Taiwan's Modernization in Global Perspective}

\section{Edited by Peter C.Y. Chow}

Foreword by Kuang-Sheng Liao

Taiwan's modernization and increasing economic affluence is offered as an example for developing countries.

$2002 \cdot 392$ pages $\cdot 0-275-97080-9 \cdot \$ 71.95$

\section{American Shockwave \\ Entrepreneurial Capitalism \\ and its Global Impact \\ By Kim Ezra Shienbaum}

"Economic development professionals will be thrilled..."

Paul Raetsch

Regional Director

Economic Development Administration

U.S. Department of Commerce

Shienbaum argues that the New Economy was catalyzed by federal policymaking encouraging salutary market behaviors.

$2002 \cdot 200$ pages $\cdot 0-275-97483-9 \cdot \$ 64.95$

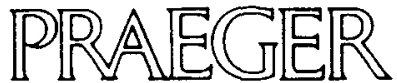

Praeger is an imprint of the Greenwood Publishing Group

88 Post Road West • P.O. Box 5007 Westport, CT 06881-5007 • Order Fax (203) 750-9790 


\section{SUBSTANTIVE. \\ COMPEILJIS. \\ THOU GHFEL \\ RIGOROUS}

Ethics \&

International

Affairs
"The Carnegie Council's distinguished journal, Ethics \& International Affairs, has found a niche in the crowded market for international journals by applying ethical, religious, and philosophical insights to global affairs."

-Foreign Policy

2002 VOLUME 16 NUMBER 1

Introducing the ROUNDTABLE and DEBATE sections . . . and a new look

Richard Falk, Ruth Wedgwood, William L. Nash, Fawaz A. Gerges, and George A. Lopez engage in a discussion on the legal, moral, and military rules that apply in the "war" on terrorism

Douglas Klusmeyer and Astri Suhrke explore the legal and policy implications of the rhetorical use of "evil"

Peter Singer and Andrew Kuper debate Singer's controversial views on poverty relief

S. Prakash Sethi argues that MNCs have an unfair advantage in the current global economic system and proposes a framework for workable codes of conduct

Ethics \& International Affairs is published twice yearly. Subscription rates: Individual: $\$ 20$ domestic, $\$ 30$ international.

Institutional: $\$ 60$ domestic, $\$ 75$ international.

Publications Fulfillment Department

Carnegie Council on Ethics and International Affairs

170 East 64th Street, NY, NY 10021-7496

$212 / 838.4120$ - fax: $212 / 752.2432$

info@cceia.org - Order online at: www.carnegiecouncil.org 


\section{Global Community}

The Role of International Organizations

in the Making of the Contemporary World

\section{AKIRA IRIYE}

"According to Iriye, scholars have been so preoccupied with high politics and state-centered activities that they have failed to pay attention to other phenomena that better explain the emergence of the contemporary world. This history of international organizations in the twentieth century is a pioneering effort to remedy that shortcoming."

-Frank Ninkovich, author of The United States and Imperialism

"This remarkable book shifts the focus of postwar international history away from Cold War rivalries and onto the astonishingly robust growth of international non-governmental organizations. A powerful voice for internationalism, Iriye should be required reading for the twenty-first century."

-Emily S. Rosenberg, author of Financial Missionaries to the World \$29.95 CLOTH

At bookstores or order (800) 822-6657 - www.ucpress.edu University of California Press

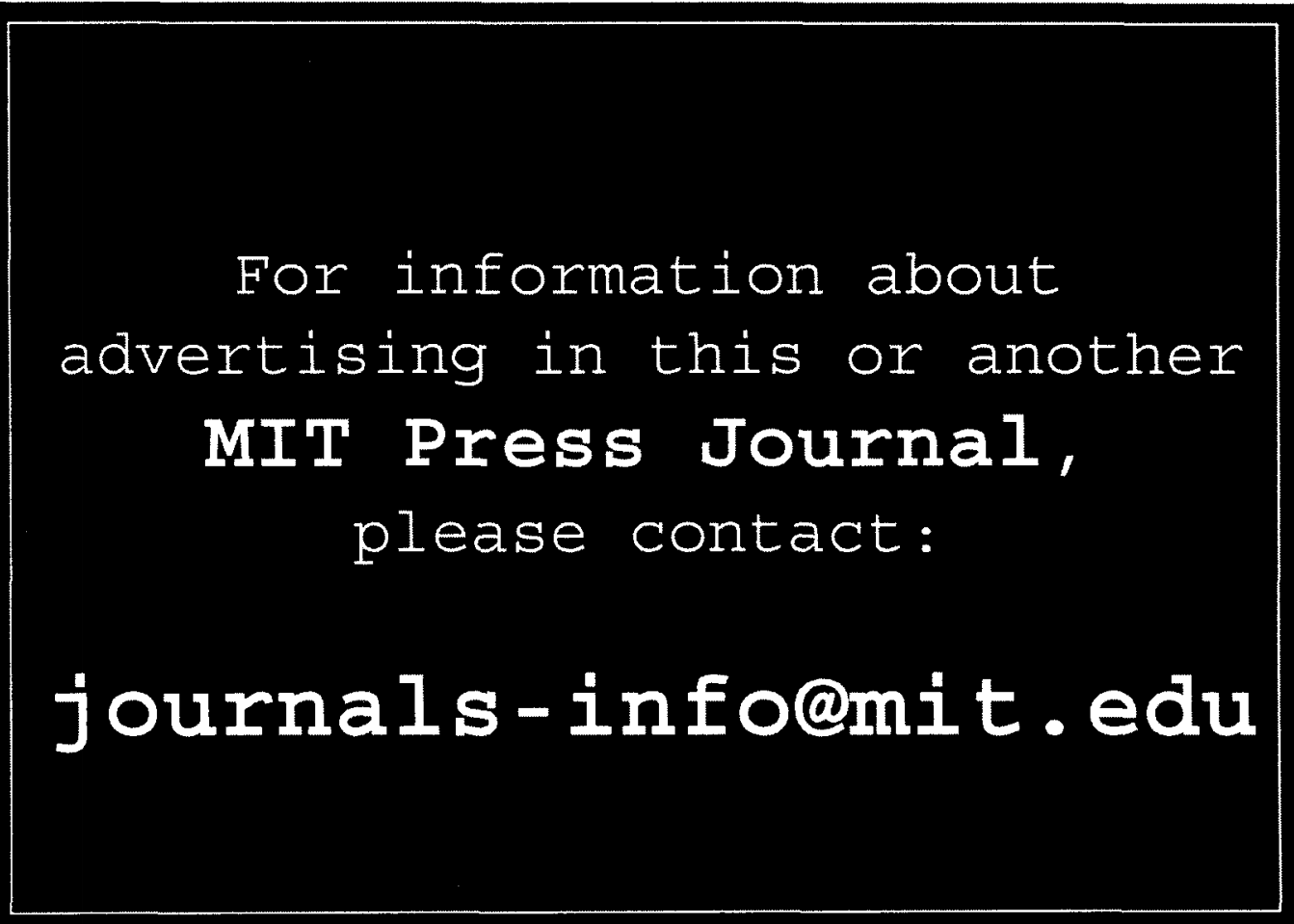


"For [over] twenty years IS has been influencing scholarship and public discourse.

On a wide range of topics, it has become our most interesting and important journal." -Robert Jervis, Columbia University

"The best journal in the field." -Kenneth Waltz,
University of California, Berkeley "Absolutely indispensable." -Samuel P. Huntington, Harvard University

"A forum for the most important scholarship on international security issues." -Benjamin Frankel, Editor, Security Studies

\section{"Excellent." -The Times Higher Education Supplement}

For over twenty years, International Security has published articles that have defined the debate on all aspects of war, peace, and security studies. Its lucid and well-documented essays come from all political and theoretical perspectives. Subscribers receive the most provocative and most frequently cited articles on today's security agenda.

Steven E. Miller: Editor in Chief

Michael E. Brown, Sean M. Lynn-Jones and Owen R. Coté, Jr., Editors

http://mitpress.mit.edu/ISEC

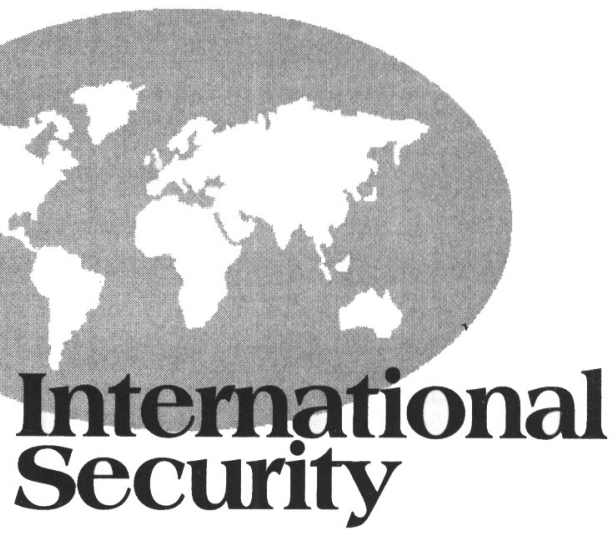

Select Recent Contributions

The Myth of Air Power in the Persian Gulf War and the Future of Warfore

Daryl G. Press

The Rise and Fall of the South African Bomb

Peter Liberman

Human Security-Poradigm Shift or Hot Air?

Roland Paris

Chino's Use of Force, 1950-96, and Toiwan

Allen S.Whiting

The full text of is is available online through The MIT Press.

MIT Press Journals

Five Cambridge Center

Cambridge, MA 02142 USA

617-253-2889 tel

617-577-1545 fax

journals-orders@mit.edu

Published quarterly by The MIT Press for the Center for Science and International Affairs, Harvard University. ISSN 0162-2889 / E-ISSN |531-4804 


\section{INTERNATIONAL POLITICAL SCIENCE ABSTRACTS DOCUMENTATION POLITIQUE INTERNATIONALE 27, rue Saint-Guillaume, 75337 PARIS CEDEX 07, FRANCE \\ Fax : + 33. 145490149 \\ E-mail : ipsa-aisp@sciences-po.fr}

Published since 1951 by the International Political Science Association (all back volumes are available), the Abstracts is a major source of bibliographic information in political science. It publishes abstracts of articles in specialized and non specialized periodicals, including major yearbooks. Articles in English are abstracted in English; those in other languages (about one fifth of the total) are abstracted in French, with all titles translated into English. In 2001 it published 7,537 abstracts from nearly 1,000 journals, in six issues. Each issue carries a detailed subject index (cumulative for all previous issues of the same year) and a list of the periodicals examined. The final issue of each volume also provides an author index.

\section{SPECIAL INTRODUCTORY OFFER : FREE EXAMINATION COPY TWO YEARS AT HALF PRICE PLUS ONE BACK VOLUME FREE}

For volumes 51 (2001) and 52 (2002), new institutional subscribers are granted a 50 percent reduction, and pay only US $\$ 180$ per volume, instead of approximately US $\$ 360$ (the equivalent of Euros 408). Payment may be made for volume 52 only, or for both volumes 51 and 52 . On request, new subscribers will receive all issues of volume 50(2000) as an introductory present. They can order all back volumes at half-price. Do not hesitate to ask for a free examination copy.

\section{NOW ALSO AVAILABLE ONLINE AND ON CD-ROM}

International Political Science Abstracts on CD-Rom, with data from 1989 to the present, contains nearly 87,000 records at the end of 2001 . The database is updated four times a year.

Publisher : SilverPlatter Information 100 River Ridge Drive Norwood, MA 02062 USA Price : US \$ 1275 Current print subscribers are entitled to Tel: +1-800-343-0064 or +1-781-769-2599 Fax : +1-781-769-8763 E-mail : info@silverplatter.com

The above price is for stand alone subscriptions. For networking prices, please call SilverPlatter. A $50 \%$ discount is granted to subscribers in developing countries.

The annual subscription consists of quarterly updates which subscribers can use in the search environment of their choice-on their local installation via Windows, Macintosh, or DOS interface, or from SilverPlatter's Internet Service via Windows or Web interface. 


\section{International Studies from Cambridge}

\section{Review of International Studies}

Published for the British International Studies Association

Founded in 1974 as the flagship journal of the British International Studies Association, Review of International Studies serves the needs of scholars in international relations and related fields such as politics, history, law, and sociology. From 2002 the Review of International Studies has a new team of Editors based in the Politics Department at the University of Exeter. The Review's primary aim is to publish research articles of the highest quality and review articles which survey new contributions to the field. It will continue to offer a forum section to accommodate debates and replies, occasional interviews with leading scholars and practitioners and a special issue published biennially.

Other titles of interest also published by Cambridge Journals include.

- European Review

- Social Philosphy and Policy

- Contemporary European History

- British Journal of Political Science

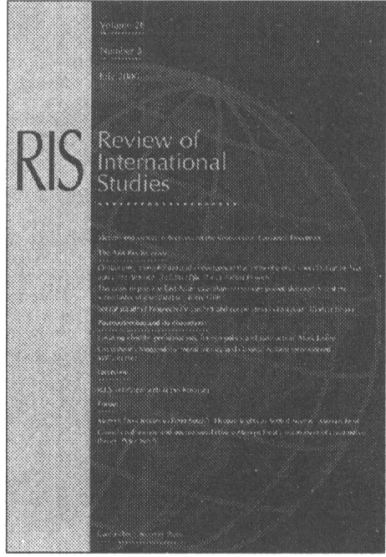

\section{Online Access}

The journal is online at Cambridge Journals Online.

Visit Cambridge Journals for free access to abstracts and tables of contents.

\section{http://journals.cambridge.org}

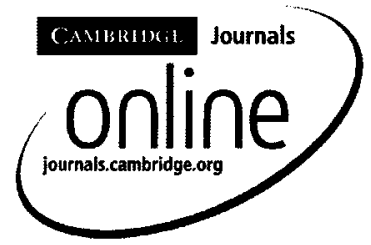

For further information regarding current subscription rates please visit our website at http://www.cambridge.org or contact Customer Services at the address below.

to contact the Customer Senvices Journals Division -

in Cambridge: tel +44 (0)1223326070 fax +44 (0)1223 325150 email journals@cambridge.org in New York: tel (914) 9379600 fax (914) 9374712 email subscriptions_newyork@cambridge.org 
The Institutional

\section{Dimensions of}

\section{Environmental}

\section{Change}

Fit, Interplay, and Scale

Oran R. Young

"This book is an authoritative effort to inject a degree of intellectual order into a field of research still characterized by widespread interdisciplinary confusion. It will not only be a major contribution to the literature in this field; it is likely to become a standard reference source for future research."

- Peter H. Sand, University of Munich

Global Environmental Accord: Strategies for Sustainability and Institutional Innovation series 232 pp., 1 illus. \$21.95 paper

\section{State Making} and Environmental Cooperation

Linking Domestic and International Politics In Central Asla

\section{Erika Weinthal}

"Should be required reading for those wanting to know more about Central Asia, environmental security, and international collaboration in the region."

- Sarah E. Mendelson, Tufts University, co-editor, The Power and Limits of NGOs

Global Environmental Accord: Strategies for Sustainability and Institutional innovation series 288 pp. 6 illus. $\$ 23.95$ paper

\section{Engendering International Health}

The Challenge of Equity edited by Gita Sen, Asha George, and Piroska Östlin

"A must for all global health scientists, policy-makers, and practitioners." - Lincoln Chen, Harvard University

Basic Bioethics series

A Bradford Book

510 pp., 21 illus. $\$ 24.95$ paper

To order call 800-405-1619.

Prices subject to change without notice.

\section{Environmental} Impacts of Globalization and Trade

\section{A Systems Study}

Corey L. Lofdahl

"This intriguing study applies lateral pressure theory previously used to understand greatpower wars to global Nor th South relations and the environmental consequences of free trade. Lofdahl's work is notable for its use of multiple methodologies to analyze complex systems."

- Joshua S. Goldstein, American University

Global Environmental Accord: Strategies for Sustainability and Institutional Innovation series 272 pp., 65 illus. $\$ 32.95$

\section{Borders and Brethren}

Iran and the Challenge of Azerbaljanl Identity Brenda Shaffer

"One of the few works that looks seriously at Iranian Azerbaijan, Shaffer's book is a major contribution to the history of both Iranian and Soviet nationality policies."

- Ronald Grigor Suny,

University of Chicago

BCSIA Studies in International

Security

300 pp. $\$ 22.95$ paper

\section{now in paperback}

\section{Political \\ Economics}

Explaining Economic Policy

Torsten Persson

and Guido Tabellini

Combining the best of three separate traditions-the theory of macroeconomic policy, public choice, and rational choice in political science-Torsten Persson and Guido Tabellini suggest a unified approach to the field.

Zeuthen Lecture Book Series 551 pp., 11 illus. \$30 paper

new from the mit press

\section{The Middle East Military Balance, 2001-2002}

\section{Shlomo Brom}

and Yiftah Shapir

"Provides the most comprehensive and objective analysis of Middle East military developments available in the open literature. A first-rate product." - Geoffrey Kemp, Director of Regional Strategic Programs, The Nixon Center

BCSIA Studies in Internationa Security

400 pp. $\$ 37.95$

\section{Global Justice and Transnational Politics}

edited by Pablo De Greiff and Ciaran Cronin

Essays exploring the prospects for transnational democracy in a world of increasing globaliza tion.

328 pp. \$22.95 paper

now in paperback

\section{The Wind of the Hundred Days}

How Washington Mismanaged Globalization Jagdish Bhagwati

"An impressive sequel to his earlier collection of public policy essays, A Stream of Windows." - Jeffrey Frankel,

Foreign Affairs

408 pp., 13 illus. $\$ 21.95$ paper

now in paperback

Keys to Prosperity

Free Markets, Sound Money, and a Bit of Luck

Rudi Dornbusch

"Highly stimulating commentary on contemporary issues of enduring interest." - Foreign Affairs

369 pp., 34 illus. $\$ 17.95$ paper

http://mitpress.mit.edu 


\section{Keep informed with \\ International Organization}

Whether your main interest is in international relations, business, or finance, you can't afford to be without the timely, authoritative, and influential articles in INTERNATIONAL ORGANIZATION. Order your personal subscription today and join the experts in universities, embassies, corporations, and international think tanks who must read INTERNATIONAL ORGANIZATION to keep informed of today's shifting alliances and international market activity. The full text of IO is now available online from The MIT Press. For an additional $\$ 50$ annual fee, individual subscribers can now access IO back volumes 1 to 50 available online from JSTOR.

_ This is a new subscription.

- This is a renewal. My account number is (see label)

Your subscription will begin with Vol. 56, No. 1 (Winter 2002).

_ This is a gift. (Please attach recipient's name/address as well as your own.)

\begin{tabular}{|c|c|c|c|c|c|}
\hline \multicolumn{2}{|l|}{2002 RATES (check one) } & \multicolumn{2}{|c|}{$\rightarrow$ Print E Electronic - } & \multicolumn{2}{|c|}{ - Electronic Only- } \\
\hline & U.S. & Canada* & All Other Countries & U.S. E Foreign & Canada* \\
\hline Individual & 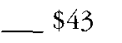 & $\ldots 46.01$ & $\ldots \$ 63$ & $\ldots \$ 39$ & $\$ 41.73$ \\
\hline Institution & $\ldots 140$ & $-\$ 149.80$ & $\ldots 160$ & $\ldots \$ 126$ & $\ldots 134.82$ \\
\hline Student**/Retired & $\$ 27$ & $\ldots 28.89$ & $\ldots \$ 47$ & $\ldots \$ 24$ & $\ldots 25.68$ \\
\hline${ }^{*}$ Price reflects $7 \%$ GST. & ${ }^{* *} \mathrm{Copy}$ & rrent ID $r$ & ed & & \\
\hline Access Fee to JSTOR & $\$ 50$ & & & & \\
\hline
\end{tabular}

\section{Prepayment required}

Check or money order enclosed, payable to International Onganization.

(check must be drawn against a U.S. bank in U.S. funds)

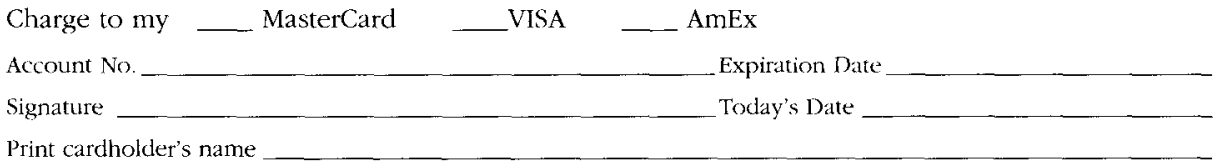

Send the subscription to: (please print clearly)

Name __________________________________________ phone

Company/Dept. ______________________________________

Address

City/State/Province/Zip/Country

For ordering information on back issues, contact:

Circulation Department

MIT Press Journals

Five Cambridge Center

Cambridge, MA 02142

Tel: $617-253-2889$

Fax: 617-577-1545

journals-orders@mit.edu

http://mitpress.mit.edu/IO
To subscribe, send this form with your payment to the Circulation Department at the address at left or order by phone, fax or email. 


\section{International Organization}

Volume 56 Number 2 Spring 2002

International Organization (ISSN 0020-8183) is published quarterly (winter, spring, summer, and autumn) by The MIT Press, Five Cambridge Center, Cambridge, MA 02142-1407. An electronic, full-text version of $1 O$ is available from the MIT Press. Subscriptions and address changes should be addressed to MIT Press Journals, Five Cambridge Center, Cambridge, MA 02142-1407; telephone (617) 253-2889; fax (617) 577-1545; e-mail: journalsorders@mit.edu. Subscriptions are on a volume year basis. Subscription rates: Electronic only-Individuals $\$ 39.00$, Students/retired $\$ 24.00$. Institutions $\$ 126.00$. Canadians add $7 \%$ GST. Print and Electronic-Individuals \$43.00, Students/retired \$27.00. Institutions $\$ 140.00$. Outside the U.S. and Canada add $\$ 20.00$ for postage and handling. Canadians add the 7\% GST. Single Issues - Current issues are $\$ 14.00$. Back issue rates: Individuals $\$ 19.00$, Institutions $\$ 38.00$. Outside the U.S. and Canada add $\$ 5.00$ for postage and handling. Canadians add 7\% GST. For an additional $\$ 50.00$ annual fee, individual subscribers can access 10 back volumes $1-49$, available online from JSTOR. Claims for missing issues will be honored free of charge if made within three months after the publication date of the issue. Claims may be submitted to: journals-claims@mit.edu. Prices subject to change without notice. Postmaster: Send address changes to International Organization, Five Cambridge Center, Cambridge, MA 02142-1407. Periodicals postage paid at Boston and additional mailing offices.

International Organization is abstracted or indexed in the following: Academic Abstracts, ABC Pol Sci, America: History and Life, Communication Abstracts, Current Contents/Social \& Behavioral Sciences, Current Law Index, Deep Sea Research \& Oceanographic Abstracts, Energy Research Abstracts, Expanded Academic Index, Future Survey, Historical Abstracts, Human Rights Internet Reporter, INIS Atomindex, Index of Economics Articles, International Bibliography of Economics (also in IBSS), International Bibliography of Periodical Literature, International Bibliography of the Social Sciences/Political Science, International Labour Documentation, International Political Science Abstracts, Journal of Economic Literature, Key to Economic Science, Legal Research Index, Magazine Index (Information Access Company), Middle East: Abstracts and Index, Public Affairs Information Service/ PAIS, Recently Published Articles, Rural Recreation and Tourism, SCIMP (Selective Cooperative Index of Management Periodicals), Social Sciences Citation Index, Social Sciences Index, Social Science Source, Sociological Abstracts, World Agricultural Economics \& Rural Sociology Abstracts.

Advertising and mailing list rental: Please write to Marketing Department, MIT Press Journals, Five Cambridge Center, Cambridge, MA 02142-1407 USA, or telephone (617) 253-2866, fax (617) 258-5028, e-mail: journals-info@mit.edu.

Rights and permissions: All inquiries concerning rights and permissions should be sent to Subsidiary Rights Manager, MIT Press Journals, Five Cambridge Center, Cambridge MA 02142-1407; telephone (617) 253-2864; fax (617) 258-5028; e-mail: journalsrights@mit.edu. Permission to photocopy articles for internal or personal use or the internal or personal use of specific clients is granted by The IO Foundation and the Massachusetts Institute of Technology for libraries and other users registered with the Copyright Clearance Center (CCC), provided that the fee of $\$ 8.00$ per copy is paid directly to CCC, 222 Rosewood Drive, Danvers, MA 01923. The fee code for users of the Transactional Reporting Services is $0020-8183 / 02 \$ 8.00$. For those organizations that have been granted a photocopy license with $\mathrm{CCC}$, a separate system of payment has been arranged. 


\section{A Journal of \\ Political and \\ Economic Affairs}

Edited at the Weatherhead Center

for International Affairs,

Harvard University

Published by The MIT Press 